\title{
HUBUNGAN PENGETAHUAN, SIKAP DAN KENYAMANAN PEKERJA DENGAN PEMAKAIAN ALAT PELINDUNG DIRI (APD) DI BENGKEL LAS LISTRIK KECAMATAN AMUNTAI TENGAH KABUPATEN HSU TAHUN 2016
}

\author{
Gusti Permatasari, Gunung Setiadi, Arifin \\ Poltekkes Kemenkes Banjarmasin Jurusan Kesehatan Lingkungan \\ Jl. H. Mistar Cokrokusumo No.1A Banjarbaru Kalimantan Selatan 70714 \\ E-mail: gustisari86@yahoo.com
}

\begin{abstract}
Relations Of Knowledge, Attitude And Comfort Of Personal Protective Equipment (PPE) In Las Electrical Workshop Subdistrict Central Amuntai Regency Hulu Sungai Utara 2016. Means work safety and health is one of the aspect protection of the labour to achieve optimal productivity. The means of the implementation of the safety and health of work, use of personal protection equipment (PPE) is a last choice in protecting the safety and health for workers of hazards potential. The results of a preliminary survey shows $60 \%$ on 10 workers of the las electrical workshop knowing the benefits and usefulness of the APD. The comfort factor of $80 \%$ felt less comfortable. The purpose of the study is to know the relations of knowledge, attitude and comfort with the use of personal protective equipment (PPE) in las electrical workshop Subdistrict Amuntai Central Regency Hulu Sungai Utara. The benefits of this research are as information materials and evaluation to find out the factors that affect its relationship with workers wearing of personal protection equipment (PPE). The research method used analytic survey with cross sectional design. Population of research to 40 people.Data analysis used $\mathrm{X}^{2}$ (Chi-Square). The results showed : (1) knowledge $(p=0,000),(2)$ attitude $(p=0,025)$, comfort $(p=0.002)$. The results showed that there is a relationship of knowledge, attitude and comfort with the use of personal protective equipment (PPE) in las electrical workshop Subdistrict Central Amuntai Regency Hulu Sungai Utara. An increase in oversight activities of las electrical workshops of workers so that workers work safely as wearing the of personal protective equipment (PPE) when working.
\end{abstract}

Keywords: PPE; knowledge; attitude; comfort

Abstrak: Hubungan Pengetahuan, Sikap dan Kenyamanan Pekerja Dengan Pemakaian Alat Pelindung Diri (APD) di Bengkel Las Listrik Kecamatan Amuntai Tengah Kabupaten Hulu Sungai Utara Tahun 2016. Upaya keselamatan dan kesehatan kerja merupakan salah satu aspek perlindungan tenaga kerja untuk mencapai produktivitas kerja yang optimal. Upaya penerapan keselamatan dan kesehatan kerja, penggunaan APD merupakan pilihan terakhir dalam melindungi keselamatan dan kesehatan pekerja dari potensi bahaya. Hasil survey pendahuluan menunjukan $60 \%$ pada 10 pekerja bengkel las listrik mengetahui manfaat dan kegunaan APD. Dari faktor kenyamanan 80\% merasa kurang nyaman. Tujuan penelitian adalah untuk mengetahui hubungan pengetahuan, sikap dan kenyamanan pekerja dengan pemakaian alat pelindung diri (APD) di bengkel las listrik Kecamatan Amuntai Tengah Kabupaten Hulu Sungai Utara. Manfaat penelitian ini adalah sebagai bahan informasi dan evaluasi untuk mengetahui faktor yang mempengaruhi pekerja hubungannya dengan pemakaian alat pelindung diri (APD). Metode penelitian yang digunakan adalah survei analitik dengan pendekatan cross sectional. Populasi dalam penelitian ini berjumlah 40 orang. Analisis data menggunakan uji $\mathrm{X}^{2}$ (Chi-Square). Hasil uji penelitian menunjukan: (1) pengetahuan ( $p=0,000)$, (2) sikap ( $p=0,025)$; (3) kenyamanan $(\mathrm{p}=0,002)$. Hasil penelitian ini menunjukan ada hubungan pengetahuan, sikap dan kenyamanan pekerja dengan pemakaian alat pelindung diri (APD) di bengkel las listrik Kecamatan Amuntai Tengah Kabupaten Hulu Sungai Utara. Adanya peningkatan pengawasan kegiatan pekerja bengkel las listrik.

Kata Kunci: APD; pengetahuan; sikap; kenyamanan 


\section{PENDAHULUAN}

Setiap pekerjaan selalu

mengandung potensi risiko bahaya dalam bentuk kecelakaan kerja. Besarnya potensi kecelakaan dan penyakit akibat kerja tersebut tergantung pada jenis produksi, teknologi yang dipakai, bahan yang digunakan, tenaga kerja dan sebagainya, begitu juga dengan industri bengkel las.

$\begin{array}{ccc}\text { Pada } & \begin{array}{c}\text { industri } \\ \text { kerja }\end{array} & \text { las, } \\ \text { lingkungandisi } & \text { berpotensi }\end{array}$ menimbulkan dampak terhadap pekerja diantaranya adalah sinar ultra violet dan sinar inframerah sebagai akibat pejanan dalam kegiatan pengelasan. Sinar-sinar tersebut apabila terus menerus mengenai pekerja dapat mengiritasi lensa mata yang ditandai dengan keluhan rasa pedih, gatal dan pandangan menjadi gelap dalam sementara waktu (22).

Bahaya-bahaya lingkungan kerja baik bahaya fisik maupun bahaya kimia perlu dikendalikan sedemikian rupa sehingga tercipta suatu lingkungan kerja yang sehat dan nyaman. Bahaya-bahaya lingkungan kerja tersebut seperti kecelakaan dan penyakit akibat kerja. Terdapat barbagai cara untuk menanggulangi bahaya-bahaya tersebut yaitu pengendalian secara teknik (mechanical/engineering control), pengendalian secara administratif (administrative control) dan alat pelindung diri (personal protective equipment) (22).

Upaya keselamatan dan kesehatan kerja merupakan salah satu aspek perlindungan tenaga kerja untuk mencapai produktivitas kerja yang optimal. Berkaitan dengan upaya penerapan keselamatan dan kesehatan kerja, penggunaan APD merupakan pilihan terakhir dalam melindungi keselamatan dan kesehatan pekerja dari potensi bahaya, dalam hal ini APD dilakukan setelah pengendalian teknik dan administratif tidak mungkin lagi diterapkan salah satu upaya untuk melindungi sebagian atau seluruh tubuh pekerja dari adanya potensi bahaya atau kecelakaan kerja (4).
Terkait tentang pemakaian alat pelindung diri (APD) dari hasil wawancara pada 10 pekerja las listrik terdapat $60 \%$ dari 6 pekerja yang mengetahui akan pentingnya, manfaat dan kegunaan APD dan 40\% dari 4 pekerja kurang mengetahui. Pemakaian alat pelindung diri (APD) pada saat bekerja tergantung sikap atau kesadaran diri masing-masing pekerja, karena sikap adalah kecenderungan sesorang untuk bertindak. Dari segi faktor kenyamanan $80 \%$ pekerja mengatakan bahwa memakai alat pelindung diri (APD) kurang nyaman dan risih.

\section{BAHAN DAN CARA PENELITIAN}

Metode penelitian yang digunakan adalah survei analitik dengan pendekatan cross sectional. Populasi penelitian ini adalah seluruh pekerja bengkel las listrik di Kecamatan Amuntai Tengah yang berjumlah 40 orang pekerja. Yang menjadi variabel penelitian ini adalah variabel bebas yaitu pengetahuan, sikap dan kenyamanan. Variabel terikat pemakaian alat pelindung diri (APD). Metode pengambilan sampel yang digunakan pada penelitian ini adalah menggunakan sampel jenuh atau sampling jenuh yaitu teknik pengumpulan sampel bila semua anggota populasi digunakan sebagai sampel (25). Data yang diperoleh diolah secara manual, disajikan dalam bentuk tabel distribusi frekuensi. Untuk mengetahui hubungan pengetahuan, sikap dan kenyamanan pekerja pekerja las listrik dengan pemakaian APD di bengkel las listrik Kecamatan Amuntai Tengah Kabupaten Hulu Sungai Utara, dianalisis dengan menggunakan perhitungan statistik yaitu dengan bantuan komputer dengan uji $\mathrm{X}^{2}$ (Chi-Square). Instrumen yang digunakan dalam penelitian ini yaitu kuesioner. Kuesioner adalah sebuah daftar pertanyaan yang harus diisi oleh orang yang akan diukur (responden).

\section{HASIL PENELITIAN DAN PEMBAHASAN}

Hasil data distribusi responden dengan pemakaian alat pelindung diri (APD) pada pekerja bengkel las listrik. 
Tabel 1. Data Distribusi Responden Berdasarkan Pemakaian Alat Pelindung Diri (APD) Pekerja Bengkel Las Listrik di Kecamatan Amuntai Tengah Kab. HSU Tahun 2016

\begin{tabular}{cccc}
\hline \multirow{2}{*}{ No } & \multirow{2}{*}{ Alat Pelindung Diri } & $\mathrm{n}$ & Jumlah \\
& & 30 & $\%$ \\
\hline 1 & Tidak menggunakan APD & 10 & 75 \\
2 & Menggunakan APD & 40 & 25 \\
\multicolumn{2}{r}{ Total } & 100 \\
\hline
\end{tabular}

\begin{abstract}
Berdasarkan tabel 1 diketahui bahwa responden yang tidak menggunakan APD sebanyak 30 orang (75\%) dan menggunakan APD sebanyak 10 orang $(25 \%)$.
\end{abstract}

Tabel 2. Data Distribusi Pengetahuan Responden Tentang Pemakaian Alat Pelindung Diri (APD) Pekerja Bengkel Las Listrik di Kecamatan Amuntai Tengah Kab. HSU Tahun 2016.

\begin{tabular}{ccccc}
\hline \multirow{2}{*}{ No } & & \multirow{2}{*}{ Pengetahuan } & $\mathrm{n}$ & Jumlah \\
& & & 24 & $\%$ \\
\hline 1 & Kurang Baik & & 16 & 60 \\
2 & Baik & \multirow{2}{*}{ Total } & 40 & 40 \\
& & &
\end{tabular}

Berdasarkan tabel 2 diketahui bahwa responden yang memiliki pengetahuan yang kurang baik tentang pemakaian APD berjumlah 24 orang (60\%). Responden yang memiliki
Hasil data distribusi pengetahuan responden tentang pemakaian alat pelindung diri (APD) pekerja bengkel las listrik.

pengetahuan baik berjumlah 16 orang $(40 \%)$

Hasil data distribusi sikap responden tentang pemakaian alat pelindung diri (APD) pada pekerja bengkel las listrik.

Tabel 3. Data Distribusi Pengetahuan Responden Tentang Pemakaian Alat Pelindung Diri (APD) Pekerja Bengkel Las Listrik di Kecamatan Amuntai Tengah Kab. HSU Tahun 2016.

\begin{tabular}{ccccc}
\hline \multirow{2}{*}{ No } & \multirow{2}{*}{ Sikap } & n & Jumlah \\
\hline 1 & Kurang Baik & & 22 & 55 \\
2 & Baik & & 18 & 45 \\
& & Total & 40 & 100 \\
\hline
\end{tabular}

Berdasarkan tabel 3 diketahui bahwa responden yang memiliki sikap yang kurang baik tentang pemakaian APD berjumlah 22 orang (55\%). Responden yang memiliki pengetahuan baik berjumlah 18 orang (45\%).
Hasil data distribusi kenyamanan responden tentang pemakaian alat pelindung diri (APD) pada pekerja bengkel las listrik. 
Tabel 4. Data Distribusi Kenyamanan Responden Tentang Pemakaian Alat Pelindung Diri (APD) Pekerja Bengkel Las Listrik di Kecamatan Amuntai Tengah Kab. HSU Tahun 2016.

\begin{tabular}{cccc}
\hline \multirow{2}{*}{ No } & Kenyamanan & $\mathrm{n}$ & Jumlah \\
\hline 1 & Kurang nyaman & 36 & 90 \\
2 & Nyaman & 4 & 10 \\
& Total & 40 & 100 \\
\hline
\end{tabular}

Berdasarkan tabel 4 diketahui bahwa responden yang merasa kurang nyaman tentang pemakaian APD berjumlah 36 orang (90\%). Responden yang merasa nyaman berjumlah 4 orang $(10 \%)$.
Hasil data hubungan antara pengetahuan dengan pemakaian alat pelindung diri (APD) pada pekerja bengkel las listrik.

Tabel 5. Hubungan Antara Pengetahuan dengan Pemakaian Alat Pelindung Diri (APD) Pekerja Bengkel Las Listrik Di Kecamatan Amuntai Tengah Kab. HSU Tahun 2016

\begin{tabular}{llcccccc}
\hline & \multicolumn{8}{c}{ Pemakaian Alat Pelindung Diri (APD) } \\
\multirow{2}{*}{ No } & Pengetahuan & \multicolumn{7}{c}{ Tidak menggunakan APD } & \multicolumn{2}{c}{ Menggunakan APD } & \multicolumn{2}{c}{ Total } \\
& & $\mathrm{N}$ & $\%$ & $\mathrm{n}$ & $\%$ & $\sum$ & $\%$ \\
\hline 1 & Kurang baik & 23 & 95,8 & 1 & 4,2 & 24 & 100 \\
2 & Baik & 7 & 43,8 & 9 & 56,3 & 16 & 100 \\
& Total & 30 & 75 & 10 & 25 & 40 & 100 \\
\hline
\end{tabular}

Berdasarkan tabel 5 dapat diketahui dari 24 responden yang memiliki pengetahuan kurang baik terdapat 23 orang $(95,8 \%)$ yang tidak menggunakan APD dan 1 orang (4,2\%) yang menggunakan APD. Pada 16 responden yang memiliki pengetahuan baik terdapat 7 orang $(43,8 \%)$ yang tidak memakai APD dan 9 orang $(56,3 \%)$ yang menggunakan APD.

Tabel 6. Hubungan Antara sikap dengan Pemakaian Alat Pelindung Diri (APD) Pekerja Bengkel Las Listrik Di Kecamatan Amuntai Tengah Kab. HSU Tahun 2016

\begin{tabular}{|c|c|c|c|c|c|c|c|}
\hline \multirow{3}{*}{ No } & \multirow{3}{*}{ Sikap } & \multicolumn{6}{|c|}{ Pemakaian Alat Pelindung Diri (APD) } \\
\hline & & \multicolumn{2}{|c|}{ Tidak menggunakan APD } & \multicolumn{2}{|c|}{ Menggunakan API } & \multicolumn{2}{|c|}{ Total } \\
\hline & & $\mathrm{N}$ & $\%$ & $\mathrm{n}$ & $\%$ & $\sum$ & $\%$ \\
\hline 1 & Kurang baik & 22 & 100 & 0 & 0 & 22 & 100 \\
\hline \multirow[t]{2}{*}{2} & Baik & 8 & 44,4 & 10 & 55,6 & 18 & 100 \\
\hline & Total & 30 & 75 & 10 & 25 & 40 & 100 \\
\hline
\end{tabular}

Berdasarkan tabel 6 dapat diketahui dari 22 responden yang memiliki sikap kurang baik terdapat 22 orang $(100 \%)$ yang tidak menggunakan
APD. Pada 18 responden yang memiliki sikap baik terdapat 8 orang $(44,4 \%)$ yang tidak menggunakan APD dan 10 orang (55,6\%) yang menggunakan APD. 
Tabel 7. Hubungan Antara kenyamanan dengan Pemakaian Alat Pelindung Diri (APD) Pekerja Bengkel Las Listrik Di Kecamatan Amuntai Tengah Kab. HSU Tahun 2016

\begin{tabular}{llcccccc}
\hline & & \multicolumn{9}{c}{ Pemakaian Alat Pelindung Diri (APD) } \\
No & Kenyamanan & idak menggunakan APD & \multicolumn{2}{l}{ Menggunakan APD } & \multicolumn{2}{c}{ Total } \\
& & $\mathrm{N}$ & $\%$ & $\mathrm{n}$ & $\%$ & $\sum$ & $\%$ \\
\hline 1 & Kurang nyaman & 30 & 83,3 & 6 & 16,7 & 36 & 100 \\
2 & Nyaman & 0 & 0 & 4 & 100 & 4 & 100 \\
& Total & 30 & 75 & 10 & 25 & 40 & 100 \\
\hline
\end{tabular}

Berdasarkan tabel 7 dapat diketahui dari 36 responden yang merasa kurang nyaman terdapat 30 orang $(83,3 \%)$ yang tidak menggunakan APD dan 6 orang $(16,7 \%)$ yang menggunakan APD. Pada responden yang merasa nyaman terdapat 4 orang $(100 \%)$ yang menggunakan APD.

\section{PEMBAHASAN}

Menurut teori Budiono tahun 2003 pemilihan penggunaan APD harus dilakukan secara baik dan bijaksana serta disesuaikan dengan potensi bahaya yang ada, guna keefektifan alat pelindung diri yang akan digunakan oleh pekerja. Dari hasil penelitian tersebut banyaknya pekerja yang tidak menggunakan alat pelindung diri karena dari 40 responden, 24 orang $(60 \%)$ dengan pengetahuan yang kurang baik tentang APD, 22 orang (55\%) dengan sikap yang kurang baik dan 36 orang $(90 \%)$ merasa kurang nyaman menggunakan APD saat melakukan pekerjaan.

Sebagian besar pekerja mengetahui seperti risiko dan bahaya dari pengelasan apabila tidak menggunakan APD dan sebagian besar pekerja kurang mengetahui fungsi dari penggunaan APD tersebut, seperti pemakaian tameng wajah dan pemakaian kacamata. Mereka beranggapan bahwa APD tersebut fungsinya sama saja yaitu temeng wajah dapat diganti dengan kacamata. Sebagian pekerja juga menganggap bahwa menggunakan APD tidak meningkatkan keselamatan kerja, mereka berangagapan bahwa memakai atau tidak memakai itu bisa saja terjadi kecelakaan kerja. Sedangkan menurut teori bahwa pemilihan penggunaan APD harus dilakukan secara baik dan bijaksana serta disesuaikan dengan potensi bahaya yang ada, guna keefektifan alat pelindung diri yang akan digunakan oleh pekerja (4).

Sikap merupakan suatu kecenderungan untuk mengadakan tindakan terhadap suatu obyek, dengan suatu cara yang menyatakan adanya tanda untuk menyenangi atau tidak menyenangi obyek tersebut (13). Hasil tersebut menunjukkan bahwa sikap baik pekerja didukung oleh pengetahuan yang baik, sehingga mereka menggunakan APD pada saat bekerja. Dan sebagian besar pekerja yang tidak menggunakan APD cenderung bertindak mengabaikan pemakaian APD ataupun memakai APD yang tidak teratur.

Pekerja yang nyaman menggunakan APD karena merasa aman bila menggunakannya pada saat bekerja terutama proses pengelasan sehingga tidak enggan menggunakannya. Banyaknya responden yang merasa kurang nyaman dengan pemakaian APD dikarenakan merepotkan, mengganggu dan risih pada saat melakukan pekerjaan, sehingga mereka enggan menggunakannya.

Dari hasil hubungan antara pengetahuan pekerja bengkel las listrik dengan pemakaian APD menunjukkan bahwa pengetahuan mempengaruhi pemakaian APD, dengan pengetahuan yang baik maka juga diterapkan oleh pekerja dengan menggunakan APD saat bekerja terutama dalam proses pengelasan begitu juga sebaliknya. Pengetahuan yang kurang baik mempunyai risiko terhadap kejadian kecelakaan kerja pada pekerja bengkel las listrik sebesar 29,571 kali (95\% CI : 3,172 
- 275,701) dibandingkan dengan pengetahuan yang baik.

Dari hasil hubungan antara sikap pekerja bengkel las listrik dengan pemakaian APD menunjukkan bahwa sikap mempengaruhi dalam pemakaian APD, pekerja yang memiliki pengetahuan baik tentang penggunaan APD, maka akan memiliki sikap positif terhadap penggunaan APD dan sebaliknya. Sikap yang kurang baik mempunyai risiko terhadap kejadian kecelakaan kerja pada pekerja bengkel las listrik sebesar 8,000 kali $\quad(95 \%$ CI : $1,425 \quad-\quad 44,920)$ dibandingkan dengan sikap yang baik.

Dari hasil hubungan antara kenyamanan pekerja bengkel las listrik dengan pemakaian APD menunjukkan kenyamanan pekerja mempengaruhi pemakaian APD, dengan adanya kenyamanan dalam penggunaan APD maka pekerja tidak enggan menggunakannya dan lebih suka menggunakan APD saat bekerja terutama dalam proses pengelasan. Pekerja yang merasa kurang nyaman menggunakan APD dan tidak menggunakannya saat bekerja dikarenakan bahwa menggunakan APD tersebut merepotkan, mengganggu, risih, merasa panas disekitar wajah sehingga mereka enggan menggunakannya dan lebih suka menggunakan kacamata las saja sebagai APD saat melakukan pengelasan. Perasaan tidak nyaman yang timbul pada saat menggunakan alat pelindung diri akan mengakibatkan keengganan tenaga kerja menggunakannya dan mereka memberi respon yang berbeda-beda. Respon tersebut yaitu menahan rasa tidak nyaman dan tetap memakai, sesekali melepas, hanya digunakan pada saat tertentu, tidak digunakan sama sekali, merasa nyaman tetap menggunakan alat pelindung diri (4).

\section{KESIMPULAN DAN SARAN}

Untuk Pemakaian alat pelindung diri (APD) pada pekerja yaitu berjumlah 30 orang $(75 \%)$ yang tidak menggunakan APD dan sebanyak 10 orang (25\%) menggunakan APD. Pengetahuan responden tentang pemakaian alat pelindung diri (APD) yaitu berjumlah 24 orang (60\%) yang kurang baik dan 16 orang $(40 \%)$ pengetahuan baik. Sikap responden tentang pemakaian alat pelindung diri (APD) yaitu berjumlah 22 orang (55\%) yang kurang baik dan 18 orang $(45 \%)$ sikap baik. Kenyamanan responden tentang pemakaian alat pelindung diri (APD) yaitu berjumlah 36 orang $(90 \%)$ yang tidak nyaman dan 4 orang $(10 \%)$ yang merasa nyaman. Ada hubungan pengetahuan pekerja dengan pemakaian alat pelindung diri (APD) di bengkel las listrik Kecamatan Amuntai Tengah Kabupaten Hulu Sungai Utara. Ada hubungan sikap pekerja dengan pemakaian alat pelindung diri (APD) di bengkel las listrik Kecamatan Amuntai Tengah Kabupaten Hulu Sungai Utara. Ada hubungan kenyamanan pekerja dengan pemakaian alat pelindung diri (APD) di bengkel las listrik Kecamatan Amuntai Tengah Kabupaten Hulu Sungai Utara. Dapat disarankan kepada pekerja bengkel las listrik pada pekerja yang mempunyai pengetahuan yang baik hendaknya dipertahankan dan mampu mempengaruhi serta membentuk sikap tenaga kerja yang lain menjadi lebih baik dan mau menggunakan APD, sedangkan untuk pemilik usaha industri bengkel las listrik yang belum mempunyai izin usaha dari instansi terkait sebaiknya membuat izin usaha agar usaha tersebut dapat diberi pengawasan dan perhatian dari instansi terkait. Sehingga peyuluhan, pelatihan kerja dapat dilakukan oleh intansi terkait maka hal tersebut dapat menambah pengetahuan pemilik usaha serta pekerja.

\section{KEPUSTAKAAN}

1. Azwar, S. (2010). Sikap Manusia Teori dan Pengukurannya. Yogyakarta : Pustaka Pelajar.

2. Badan Pusat Statistik Kabupaten Hulu Sungai Utara. 2015. http://hulusungaiutarakab.go.id/ass ets/docs/Statistik-Daerah Kabupaten-Hulu Sungai- Utara2015.pdf. Diakses tanggal 1 Febuari 2016. 
3. Bintoro, W. A. (2010). Faktor Yang Berhubungan Dengan Pemakaian AlatPelindung Muka Pada Pengelas Di Bengkel Las Listrik Kawasan Barito Kota Semarang . Skripsi Universitas Negeri Semarang .

4. Budiono, S. (2003). Bunga Rampai Hiperkes Dan Keselamatan Kerja. Semarang : Badan Penerbit Universitas Diponegoro.

5. Darmini. (2007). Analisis Faktor Yang Berhubungan Terhadap Ketajaman Penglihatan Pada Pekerja Bengkel Bagian Pengelasan Karbit Semarang. Skripsi IKM UNNES .

6. Eka, A. A. (2007). Faktor Yang Berhubungan Dengan Pemakaian Alat Pelindung Masker Pada Tenaga Pengelas Di Wilayah Karangrejo Kota Semarang. Skripsi FKM UNDIP .

7. Farida, A. M. (2006). Faktor- Faktor Yang Berhubungan Dengan Pemakaian APD pada Juru Listrik Di Wilayah Kecamatan Tembalang Kota Semarang. Skripsi FKM UNDIP.

8. Hapsari, N. D. (2003). Penggunaan Alat Pelindung Diri Bagi Tenaga Kerja. Semarang: Bunga Rampai Hiperkes dan KK UNDIP.

9. http://www.otomotifproduk.com/20 15/07/alat-pelindung-keselamatankerja posisi.html

10. http://www.depkes.go.id.2014

11. Keskerfkmunmuha, 2012 , http//keskerfkmunmuha.wordpress. com/, diakses pada 8 November 2012.

12. Mustaqim. (2008). Psikologi Pendidikan. Yogyakarta: Pustaka Pelajar.

13. Notoatmodjo, S. (2003). Ilmu Kesehatan Masyarakat PrinsipPrinsip Dasar. Rineka Cipta.

14. Notoatmodjo, S. (2005). Metodelogi Penelitian Kesehatan. Jakarta: Rineka Cipta.

15. Notoatmodjo, S. (2007). Promosi Kesehatan Dan Ilmu Prilaku. Jakarta:Rineka Cipta.

16. Putra, B. V. (2011). Analisis FaktorFaktor Yang Mempengaruhi perilaku Pekerja Pengelasan Industri Informal
Dalam Penggunaan Alat pelindung Diri (APD) Di Jalan Raya BogorDermaga, Kota Bogor. Skripsi . 
